\title{
MULTILATERALISM, DEMOCRACY, CONCERT OF POWERS: RUSSIA'S RED LINES
}

\author{
Assoc.Prof. Iulian CHIFU, PhD*
}

\begin{abstract}
The debate for resettling the world is at its peak. Different states are proposing nuanced approaches and solutions that would enable a better grip on the global governance of their own interests. Concepts are relativized and revisionism is carefully hidden beneath respect for the international rules and commitments. As is the case with democracy, embraced by all international players and subject to numerous interpretations by several actors. Multilateralism does not seem to mean the same to different stakeholders and new initiatives are challenged from the positions of a raising fear to be let aside in the big debates about the future world. But the fact is that continuity will play a role, a sophisticated system holding all alternatives will be in place and privileging one or another form is just a matter of global choice, appeal and influence of a project or another, a model or the next. This multiple circles coexistence model could be challenge by the new initiatives and their influence, the number of participants and their geopolitical footprint at the global level.
\end{abstract}

Keywords: Concert of Powers; multilateralism; power politics; Big Power Politics; spheres of influence; limited sovereignty.

Theoretical alternatives for ruling the world

The way that the international relations and global security are organized is a concern that last for ages. Actually, the whole debate about alternatives is the one depending on several lines of thinking, that created different doctrines. In theoretical terms, all models are equally interesting, with pluses and minuses. But in the real life, every model is dependent on the real situation in the world at a certain moment, quantifying the realities and power relations between the big players, the lines of thinking and the models considered close to the realities and following the trends and developments.

At the theoretical level, the models of managing the international relations sit on some very few options:

- G0 world - everybody for himself, No one's World $^{1}$, a high level of anarchy with some local or regional rules introduced in areas where there is an important actor and it has essential interests, the will to manage and observe the rules and enough resources to make those rules enforced. Subject to a consequential challenge.

- The Hegemonic world - one dominant power, with enough force, resources, and determination to shape and manage the system. It is open to contests

\footnotetext{
*"Carol I" National Defence University e-mail:keafuyul@gmail.com
}

from raising powers or alliances of different actors, and the system can work as long as there is cooperation with other big powers in the system or when there is enough capacity to enforce the rules imposed to the system.

- Big Powers' Policies - Concert of Powers Bipolarism - are solutions from the same family, with nuances.

The Big Power Policy is translated into the inclination of two major actors, Big Powers, to grant one each other mutual respect and cut a deal in a Big Bargain at the expenses of other international actors instead of making war, when it is possible.

The Concert of Powers refers to the European Concert of Powers and means that some big powers, recognizing mutually their status and interests, are negotiating a common approach to the world, common rules of cooperation, imposed, afterwards to all international players.

Bipolarism is the situation when the world is divided in two, based on ideological differences and opposite models, and these rifts are creating two opposite blocks confronting each other without involving the two Big Powers that are the center of coagulation and matrix of the two blocks. The rules and deals come also from the negotiation of the two main actors, the only superpowers or big powers in the system.

Multilateralism - means the involvement in any international decision of all the states that are international actors, with an equal footing inside the debate - equal sovereignty - through individually 
expressed preferences, majority vote, democracy and universal debate.

All the theoretical models have clear conditions for being dominants and present in the international arena:

The G0 or anarchic world is the natural form of evolution of the world when every actor is inclined to follow its own rules and interests, accommodating its relations with another actor and its own preferences, without any dominant model or rules to be imposed by somebody to the system. It is the vivid reflection of the liberty in the system. It is what we usually have in the international arena.

The Hegemonic world needs to have a major power, with enough resources and will to manage the world, at a large respect, to impose its views and models, and enforce the rules it has created. There are references for the period after the fall of the Berlin Wall with US being the hegemon in the system. But the model is more common in the Roman Empire World, Greek World, the times of the big empires which covered the known world with their rules and military power, their capacity of projecting the power and the norms and to enforce them.

The Concert of powers seems to be the most natural form of arrangement when there is a conscience to provide one and avoid conflicts of high intensity, but it relies also on the level of geopolitical power of the main actors as well as to their will and determination to be involved more than to defend their immediate individual interests. We had a few attempts, but the model did not avoid war (except for short periods of time, less than a generation). And this is possible as long as the difference of potential between those big players, big actors, and those small ones is enough to impose the dominant agreed approach without too much pain and costs.

The European Concert of Powers from Vienna,1815, the Yalta meeting between the US, Soviet Union and the UK as well as the permanent members of the Security Council, with a veto right, could be two models for seeing the Concert of Powers. Ribbentrop-Molotov secret Pact of 1939 and the Cold War period could be moments of bipolarism and mutually agreed spheres of influence, with Big Powers' Politics and Big Bargains at the expenses of other players.
Last but not least, the General Assembly debates of the UN and rules to vote non-binding resolutions are a reflection of the multilateralism.

\section{Russia's red lines. A theory of enforcing the rules at the global international level}

On the $21^{\text {st }}$ of April, Russia's President Vladimir Putin presented an Address in front of the Federal Assembly ${ }^{2}$ which became famous due to the references to the "red lines" not to be crossed. Criticizing the fact that "Western colleagues have been stubbornly rejecting Russia's numerous proposals", president Putin noted that "unfriendly movestowards Russiahavealso continuedunabated. Some countries have taken up an unseemly routine where they pick on Russia for any reason, most often, for no reason at all. It is some kind of new sport of who shouts the loudest"4.

It is in this framework and context that President Putin made his famous statement:

"We really want to maintain good relations with all those engaged in international communication, including, by the way, those with whom we have not been getting along lately, to put it mildly. We really do not want to burn bridges. But if someone mistakes our good intentions for indifference or weakness and intends to burn or even blow up these bridges, they must know that Russia's response will be asymmetrical, swift and tough.

Those behind provocations that threaten the core interests of our security will regret what they have done in a way they have not regretted anything for a long time.

At the same time, I just have to make it clear, we have enough patience, responsibility, professionalism, self-confidence and certainty in our cause, as well as common sense, when making a decision of any kind. But I hope that no one will think about crossing the "red line" with regard to Russia. We ourselves will determine in each specific case where it will be drawn"5.

So the red lines invoked are linked, in Vladimir Putin's statement, to burning or blowing up relations - lack of communication or isolation of Russia in the international arena - provocations that threaten core interests on security of Russia. Russia will establish unilaterally those red lines and enforce them and those red line will be established in a case by case manner, involving a clear threat coming from Russian part for an asymmetrical, 
swift and tough response. This approach could be easily presented as a direct threat for using the force in international affairs.

And we could see this in all the mainstream media in the West. BBC made the interpretation that Putin was warning the West ${ }^{6}$ and President's Putin spokesman Dmitry Peskov later described the "red lines" as "our external security interests, our internal security interests in preventing any outside interference, whether in our elections or other domestic political processes"7. On another point, discussing Russia's "asymmetric response" to Western actions is an old statement, but it is the first time we have the mention of existing red lines. ${ }^{8}$ There is no mention of the substance of the red lines invoked, moreover, the statement allows Russia to make a moving target of those red lines, meaning to adapt them according to its own unilateral will. At the same time, without a clear definition of Russia's red lines how could they ever be observed by someone?

The origins of the Red Lines reference (the French have the yellow lines, for the same purpose - les lignes jaunes) comes from the 1928 July 31, named Red Line Agreement ${ }^{9}$, agreement between partners of Iraq Petroleum Company not to seek independently oil interests in the Ottoman failing empire. Do not cross the given arbitrary line established in dividing a space. In real terms, it means establishing a condition that should not be challenged, with the threat to the use of force and huge costs for those breaching this condition. Now, in the international law, the red lines are forbidden per se because this enshrines a unilateral condition and the threat of using the force against an international actor.

On another point, there is a second meaning, used, for instance, by President Barack Obama in relation with the Syrian use of chemical weapons ${ }^{10}$. It is linked to the respect of international law, international established rules and commitments of one's country and establishes a limit in time or an ultimatum to withdrew from such a position and come back inside the limits of an agreed position, behavior or rules, if not to face consequences. The two interpretations are at the opposite side since the last is the one aiming at making everybody respect international law and undertaken commitments, in good faith, bona fides, or face consequences - not implying necessary the use of force, the other being a unilateral claim and related threat for the use of force.

So Russia's red lines are directly linked to a unilateral approach, illegal according to the UN Chart, condemned in the international law, including a threat to use force. The red line used by president Obama is related to enforcing the international law, the countries commitments and signature of an international treaty, being a part of the bona fides principle of respect in good faith of the commitments undertaken. From that point on we have an illustration of the antagonism between the law of the force, in the first case, and the force of law in the second.

\section{Sergey Lavrov and "true multilateralism" in the UN Security Council framework}

A sort of clarification related to Russia's red lines invoked in Vladimir's Putin State of the Nation discourse on the $21^{\text {st }}$ of April 2021 could be found in the statement of Sergey Lavrov at the online debate organized by China, in its position of chair in office of the Security Council, the $7^{\text {th }}$ of May 2021. In that speech that should have focused on a debate about multilateralism, the Minister of Foreign Affairs of the Russian Federation underlined ${ }^{11}$ his own take and that of Russia on the "true multilateralism":

"It is clear that the prospects of the international community's sustainable and predictable development are directly connected with our ability to find effective solutions to common problems and our readiness to exercise collective leadership in order for true multilateralism to prevail" ${ }^{12}$.

The red lines, described by Lavrov and Russia are: all the international rules should be established in the UN framework, with Russia having a veto power in all issues, including the New World Order ${ }^{13}$ :

"Russia, like the majority of countries, is convinced that such work must be carried out solely on the basis of universally recognized norms of international law (...). The United Nations must serve as the key platform for coordinating efforts: it is the backbone of the modern global order, where all independent states are represented. Today, its unique legitimacy and unique capabilities are especially needed. The core tenets of international law enshrined in the UN Charter have withstood the test of time. Russia calls on all states to unconditionally follow the purposes and principles of the Charter (...)" ${ }^{\prime 14}$. 
Russia is keen to come back to Yalta agreements and Big Power politics of Big Bargain in order to settle the world of tomorrow, recalling Vladimir's Putin proposal of a reunion of the Permanent Members of the UN Security Council for this deal, or at least a US-Russia meeting to set the rules of the game in the future. But, at the same time, the limits of respecting the status quo are given by "a stable balance of interests" and "the new realities" 15 which could give way for revisionism under another label:

"It is necessary to preserve the internationally recognized legal basis for building a stable balance of interests that meets the new realities (...). What could be more natural then discussing the tasks of strengthening multilateralism at the UN? (...) This also reveals the West's true attitude toward multilateralism and the UN, which they do not regard as a universal format for developing solutions acceptable to everyone" 16 .

Russia rejects the concept of rules-based world and prefers to refer to the agreed rules, meaning only those established in a UN Security Council framework:

"The concept of the rules-based order is advanced as a substitute for international law. It should be noted that international law already is a body of rules, but rules agreed at universal platforms and reflecting consensus or broad agreement. The West's goal is to oppose the collective efforts of all members of the world community with other rules developed in closed, non-inclusive formats, and then imposed on everyone else. We only see harm in such actions that bypass the UN and seek to usurp the only decision-making process that can claim global relevance" 17 .

The equal sovereignty of the states - a principle directly extracted from the UN Chart - is rejected de facto since for Lavrov, Putin and Russia, only the Big Powers are qualified to discuss the future of the world ${ }^{18}$. With Russia in the forefront, at the table:

"The permanent members of the UN Security Council are called on to play a key role in fostering open and direct dialogue about the most pressing problems of our time. According to the UN Charter, they bear special responsibility for maintaining international peace and security. President of Russia Vladimir Putin proposed convening a summit with the leaders of the five permanent members. We hope to make this idea a reality once the epidemiological situation in the world stabilizes"19.
For sure, any other reunion of sovereign states and all the agreements reached outside of the UN framework and permanent members' veto are rejected by Russia, including the Summit of Democracies and the Alliance for Multilateralism, since Russia is not present and does not held a veto power in such framework. This breaches directly the right of the states to establish agreements and negotiate mutually convened rules and commitments, also granted by the international law. And the requirement to put all international institutions, norms and agreements under the UN and Security Council veto powers is an excess of interpretation, a claim never agreed on by the international community.

"The well-known idea to convene a Summit for Democracy proposed by the US Administration is in the same vein. The establishment of a new club based on interests, with a clearly ideological nature, has the potential to further inflame international tensions and deepen dividing lines in a world that needs a unifying agenda more than ever (...). Another initiative with the goal of global leadership that bypasses the UN is the French and German idea to create an Alliance for Multilateralism (...). New ambitious initiatives to create narrow partnerships are emerging all the time within the Alliance for Multilateralism, on issues that are already being discussed at the UN or its specialized agencies, for example, on cyber security (with 65 member countries), respect for the international humanitarian law (43 member countries), the Information and Democracy Partnership (over 30 countries), etc." 20

\section{The debate about multilateralism \\ and the obvious need for a UN reform}

The real issue at stake in the idea of a multilateral system, with respect for the equal sovereignty of the states, is related to the rules of the decisions in the UN Security Council. The remains of the agreement coming from World War Two are still in place and any attempts to revise and reform the Chart in this respect have been rejected especially by the permanent members of the Security Council, in spite of the best arguments possible.

First, it was about the losing side in the WWII which did not make it in the Security Council, meaning first and foremost Germany and Japan. Then the idea of a geographically balanced presence 
would have required India, Brazil and maybe South Africa to be permanent members. If the qualified majority for a reunion of representatives, even split between permanent members and non-permanent ones, is OK for the effectiveness of the decisions. But the veto right of specific countries is a big atavism that should be replaced. But it has been rejected at all moments, even the rule of abstention from using the veto on issues related to the member state at stake.

The need for revising the UN Chart, as well as the rules of the Security Council, first and foremost the veto right of permanent members, has been identified by almost all participants in the debate about multilateralism. Even Wang Yi, the Chinese representative, and Volkan Bozkir, the Turkish diplomat holding the position of President of the General Assembly, refer to this: "On many occasions, the Council has been divided, and unable to rise to the challenge. For most of those cases, the reason for failure is the differences between its members, in particular, its permanent members", he said. Mr Bozkir highlighted the need for reform, and a more representative, accountable and transparent Council, stating "I am conveying this, as the President of the most democratic organ of our system" 21 , an indirect reference to the less democratic Security Council and its veto rights which alters the direct vote.

State Councilor and Minister for Foreign Affairs of China, Wang Yi, discussed directly the reform of the Security Council, pleading for a better representation of the developing countries: "The UN needs to keep pace with the times and should improve its efficiency, emergency response capability, and transparency of its work through reform. Earnestly increase the representation and voice of developing countries and make the global governance system more just and equitable"22.

For sure, the US has its share in the multilateral debate, which prompted the reality by recalling the basic principles of the Chart and the original understanding of the signatories. State Secretary Anthony Blinken quoted President Harry Truman for challenging the relativisation and interpretation of minister Lavrov. Maintaining peace and security is the prime objective of the UN, but human rights are present from article 1:

"The most powerful countries bound themselves to these principles. They agreed to a form of self-restraint - as President Truman put it, to deny themselves the license to do always as they pleased - because they recognized that this would ultimately serve not only humanity's interests, but their own. The United States did this, even though it was by far the most powerful nation on Earth at the time. It was enlightened self-interest. We believed other nations' success was critical to ours. And we didn't want less powerful countries feeling threatened and obliged to band together against us" ${ }^{\text {"23 }}$.

State Secretary Blinken underlined also that all the rules should be observed by the permanent members of the Security Council in the first place, and the fact that this status requires more from those members and does not grant impunity, the right to ignore the rules or taking decisions at the expenses of the smaller states. He also assumed the fact that the Chart is not for states first and foremost, but for the people, for their rights and freedoms as well:

"This boldendeavor, whateverits imperfections, has been an unprecedented achievement. And it's endured because the overwhelming majority of people and nations continue to see it as representing their interests, their values, their hopes (...). At the same time, we will continue to push back forcefully when we see countries undermine the international order, pretend that the rules we've all agreed to don't exist, or simply violate them at will. Because for the system to deliver, all countries must abide by it and put in the work for its success" 24 .

But the most important part of the statement is related to a reply to the "true multilateralism" and the system proposed by Russia, revealing, even though without naming, the most important problems and challenges at the international world order and the rules-based world coming from Putin and autocratic regimes. He challenged the reference to non-interference in internal affairs stating that "human rights are subjective values that vary from one society to another. But the Universal Declaration of Human Rights begins with the word "universal" because our nations agreed there are certain rights to which every person, everywhere, is entitled. Asserting domestic jurisdiction does not give any state a blank check to enslave, torture, disappear, ethnically cleanse their people, or violate their human rights in any other way" 25.

Anthony Blinken also referred to another principle from the Chart, the principle of the sovereign equality of its member-states, accusing 
once again Russia's behavior in the international arena:

"A state does not respect that principle when it purports to redraw the borders of another; or seeks to resolve territorial disputes by using or threatening force; or when a state claims it's entitled to a sphere of influence to dictate or coerce the choices and decisions of another country. And a state shows contempt for that principle when it targets another with disinformation or weaponized corruption, undermines other countries' free and fair elections and democratic institutions, or goes after journalists or dissidents abroad.

These hostile actions can also threaten the international peace and security that the United Nations Charter obliges this body to maintain.

When UN member-states - particularly permanent members of the Security Council - flout these rules and block attempts to hold accountable those who violate international law, it sends the message that others can break those rules with impunity".

\section{The hierarchy of international institutions versus global freedom of association}

Those evolutions are crucial in seeing the way the new world order is to be settled and how each of the countries involved in the debate are positioning themselves. We already saw the idea embraced by the US that democratic countries are in direct rivalry with the autocracies, that US is interested in a real multilateralism $^{26}$. This multilateralism involves to get together the full weight of all democracies, be it big ones, medium or small, in order to obtain the convergence of ideas and positions, the strategic weight and to obtain a dominant global majority to frame and propose the general rules ${ }^{27}$ and to defend the application of the existing principles and commitments, not only the provisions of the UN Chart.

In fact, the idea of a hierarchy of the institutions of the international system and the subordination of all organisations to the UN, and to its veto rule in the Security Council is an expression of the lack of democracy, multilateralism and equal sovereignty of the states. On the contrary, the international system including the one established through the United Nations, is based on democracy, human rights and freedom, the freedom of countries for free association and on the rules of the democratic world translated at the international stage. Supremacy of law, rule of law, sovereign equality of the states are part of the general acquis and any relativization of those rules, any rejection or limitation of the freedoms for states as for people, is a reach of this common understanding of the international law.

The fundamental anarchism of the international relations means also liberty of the states to associate the way they feel appropriate for their interests, but also in a sustainable manner, through observing the same set of principles and values - and this is the core of any agreement. The Concert of Powers has been overstated and embraced for its effectiveness ${ }^{28}$, since we are speaking about consensus between a few states. But the very experience and history of the Security Council prove that this consensus is as hard to reach as the one among a huge number of countries. On the other hand, the EU and NATO proved that if all members observe the convened rules and assume the same values and principles, you can have consensus among a relatively important number of actors.

In that respect, we have to look attentively to the new institutions for democratic cohesion. NATO has developed formats with global partners, beyond the transatlantic link, that worked in Afghanistan, and democracies could repeat this experience, with the common grounds of principles and values in the basic matrix of these organisations. The Community of Democracies is there to stay and develop, as the Summit of democracies prepared by the US could lead to a better coordination of democracies. The Alliance for multilateralism that France and Germany are preparing is another format that worth be considered. The new multilateral institutions could become instruments that could offer new instruments for monitoring the existing rules and norms, commitments and agreements, and to prepare the new rules for the needed technological developments, on cyber defence, on artificial intelligence, on space, on the Grand North and Arctic $^{29}$, and so on.

A realist design of the New World Order should have in mind a more sophisticated approach than the one over-simplified that fetishizes one of the theoretical options to resettle the World Order. In fact, all options are there and all instruments are in place, some new approaches are on the way of being framed and constructed, and the reality would allow alternative mechanisms to be present 
and useful as long as there is support for one or another at a certain moment, on given issues. In fact, all coexist and are superposed, but the states and people will refer alternatively to each of them and the most relevant with the most support will become the reference for the solution of a certain problem.

This does not mean that there are all perfect or that there will not be clashes and conflicts. But that is the way to avoid wars and open military conflicts and to discuss and cope with the problems of the world in a more adequate way that we have done during World War Two, with Ribbentrop-Molotov Pact, using the military violence and power politics, with Yalta Concert of Power, the Cold War rivalries, Big Bargain, proxy conflicts and Big Power Politics.

\section{NOTES:}

1 Kupchan Charles A, No One's World. The West, The Rising Rest and the Coming Global Turn, Oxford University Press, 2013, p. 258; Ian Bremmer, Every Nation for Itself. Winners and Loosers in a G0 World, Portfolio Penguin, 2012, p. 229.

2 Vladimir Putin, Presidential Address to the Federal Assembly, Manezh Central Exhibition Hall, April 21, 2021, http://en.kremlin.ru/events/president/news/65418

3 Ibidem.

4 Ibidem.

5 Ibidem.

6 BBC, Putin warns of tough Russian action if West crosses 'red line', 21 April 2021, https:/www.bbc.com/ news/world-europe-56828813

7 Ibidem.

8 Nikola Mikovici, What are Russia's red lines?, CGTN, 22 April 2021, https://news.cgtn.com/news/2021-0422/What-are-Russia-s-red-lines--ZF1SXkzoWc/index.html

9 Michael Quentin Morton, "Once Upon a Red Line: The Iraq Petroleum Company Story". GeoExpro, 6 April 2013, https:/www.geoexpro.com/articles/2013/06/onceupon-a-red-line-the-iraq-petroleum-company-story. To cross the red line means passing the point of no return.

10 On August 20, 2012, President Barack Obama used the phrase "red line" in reference to the use of chemical weapons in the Syrian civil war, saying, "We have been very clear to the Assad regime, but also to other players on the ground, that a red line for us is we start seeing a whole bunch of chemical weapons moving around or being utilized". When the Ghouta chemical attacks occurred. Obama then clarified "I didn't set a red line. The world set a red line when governments representing 98 percent of the world's population said the use of chemical weapons are abhorrent and passed a treaty forbidding their use even when countries are engaged in war", a reference to the Chemical Weapons Convention. See Michele Richinick Obama: "I didn't set a red line, the world set a red line", MSNBC, September 4,
2013, https://www.msnbc.com/morning-joe/obama-i-didntset-red-line-the-world-msna155636; Smith, Roff, Red line, National Geographic News, 7 May 2013, https://www. nationalgeographic.com/culture/article/130507-red-lineobama-syria-mccain-chemical-weapons; Ben Zimmer, "The Long History of the Phrase 'Red Line"', The Wall Street Journal, July 19, 2013, https://www.wsj.com/articles/SB1000 1424127887323993804578612210634238812 ; Wordsworth, Dot, "What, exactly, is a 'red line'?", The Spectator magazine, 8 June 2013, https://www.spectator.co.uk/article/ what-exactly-is-a-red-line-

11 Sergey Lavrov, Foreign Minister Sergey Lavrov's remarks at the meeting of the UN Security Council, "Maintenance of international peace and security: Upholding multilateralism and the United Nations-centred international system", held via videoconference, Moscow, May 7, 2021, https://www.mid.ru/en/posledniye_dobavlnenniye/-/asset_ publisher/MCZ7HQuMdqBY/content/id/4721942

12 Sergey Larov, op.cit.

13 Iulian Chifu, „Ucenicii vrăjitori care desenează lumea de mâine cu mâna: supra-simplificare şi paseism", Adevărul, 19 mai 2021, la adev.ro/qtc7w3

14 Sergey Larov, op.cit.

15 Iulian Chifu, „Multilateralismul Rusiei: Concertul de Putere de la Yalta, sfere de influenţă şi veto în afacerile globale", Adevărul, 11 May 2021, adev.ro/qsxepm

16 Sergey Larov, op.cit.

17 Ibidem.

18 Iulian Chifu, „Multilateralismul Rusiei: Concertul de Putere de la Yalta, sfere de influenţă şi veto în afacerile globale", Adevărul, 11 May 2021, adev.ro/qsxepm

19 Sergey Lavrov, op.cit.

20 Ibidem.

21 UN, Security Council upholds role of multilateralism in a complex world, 7 May 2021, https://news.un.org/en/ story/2021/05/1091532.

\section{Ibidem.}

23 Secretary Antony J. Blinken Virtual Remarks at the UN Security Council Open Debate on Multilateralism, May 7, 2021, https://www.state.gov/secretary-antony-j-blinken-virtualremarks-at-the-un-security-council-open-debate-onmultilateralism/

24 Ibidem.

25 Iulian Chifu, „Multilateralismul Rusiei: Concertul de Putere de la Yalta, sfere de influenţă şi veto în afacerile globale", Adevărul, 11 May 2021, adev.ro/qsxepm

26 Stewart M. Patrick, The Biden Administration and the Future of Multilateralism, European Council of Foreign Relations, 21 April 2021, https://www.cfr.org/blog/bidenadministration-and-future-multilateralism.

27 Joseph Biden Jr., Interim national security strategic guidance, White House, 3 March 2021, https://www. whitehouse.gov/wp-content/uploads/2021/03/NSC-1v2.pdf

28 Richard Haass, Charles Kupchan, The New Concert of Powers, Foreign Affairs, 23 March 2021, https://www. foreignaffairs.com/articles/world/2021-03-23/new-concertpowers

29 Iulian Chifu, ,Multilateralismul Rusiei: Concertul de Putere de la Yalta, sfere de influenţă şi veto în afacerile globale", Adevărul, 11 May 2021, adev.ro/qsxepm 


\section{REFERENCES}

*** Secretary Antony J. Blinken Virtual Remarks at the UN Security Council Open Debate on Multilateralism, 7 mai 2021, https://www.state. gov/secretary-antony-j-blinken-virtual-remarksat-the-un-security-council-open-debate-onmultilateralism/

[BBC], "Putin warns of tough Russian action if West crosses «red line»", 21 aprilie 2021, https:// www.bbc.com/news/world-europe-56828813

[UN], Security Council upholds role of multilateralism in a complex world, 7 mai 2021, https://news.un.org/en/story/2021/05/1091532

Biden Joseph Jr., Interim national security strategic guidance, White House, 3 martie 2021, https://www.whitehouse.gov/wp-content/ uploads/2021/03/NSC-1v2.pdf

Chifu Iulian, „Multilateralismul Rusiei: Concertul de Putere de la Yalta, sfere de influenţă şi veto în afacerile globale", Adevărul, 11 May 2021, adev.ro/qsxepm

Chifu Iulian, Ucenicii vrăjitori care desenează lumea de mâine cu mâna: supra-simplificare şi paseism, Adevărul, 19 May 2021, adev.ro/qtc7w3

Haass Richard, Kupchan Charles, "The New Concert of Powers", Foreign Affairs, 23 March 2021, https://www.foreignaffairs.com/articles/ world/2021-03-23/new-concert-powers

Kupchan Charles A, No One's World. The West, The Rising Rest and the Coming Global Turn, Oxford University Press, 2013; Bremmer, Ian, Every Nation for Itself. Winners and Loosers in a G0 World, Portfolio Penguin, 2012.

Lavrov Serghei, Foreign Minister Sergey Lavrov's remarks at the meeting of the UN Security Council, "Maintenance of international peace and security: Upholding multilateralism and the
United Nations-centred international system", videoconferință, Moscova, 7 May 2021, https:// www.mid.ru/en/posledniye_dobavlnenniye/-/ asset_publisher/MCZ7HQuMdqBY/content/ id/4721942

Mikovici Nikola, What are Russia's red lines?, CGTN, 22 April 2021, https://news.cgtn.com/ news/2021-04-22/What-are-Russia-s-red-lines-ZF1SXkzoWc/index.html

Morton Michael Quentin, Once Upon a Red Line: The Iraq Petroleum Company Story, GeoExpro, 6 April 2013, https://www.geoexpro. com/articles/2013/06/once-upon-a-red-line-theiraq-petroleum-company-story

Putin Vladimir, Presidential Address to the Federal Assembly, Manezh Central Exhibition Hall, 21 April, 2021, http://en.kremlin.ru/events/ president/news/65418

Richinick Michele, Obama: "I didn't set a red line, the world set a red line", MSNBC, 4 September 2013, https://www.msnbc.com/morning-joe/obama -i-didnt-set-red-line-the-world-msna155636

Smith Roff, "Red line", National Geographic News, 7 May 2013, https://www.nationalgeogra phic.com/culture/article/130507-red-line-obamasyria-mccain-chemical-weapons

Stewart M. Patrick, The Biden Administration and the Future of Multilateralism, European Council of Foreign Relations, 21 aprilie 2021, https://www.cfr.org/blog/biden-administrationand-future-multilateralism

Wordsworth Dot, "What, exactly, is a «red line»?", The Spectator Magazine, 8 June 2013, https://www.spectator.co.uk/article/what-exactlyis-a-red-line-

Zimmer Ben, "The Long History of the Phrase «Red Line», The Wall Street Journal, 19 July 2013, https://www.wsj.com/articles/SB10001424127887 323993804578612210634238812 